In conclusion, it is important to add that analyzing the advantages and disadvantages of the design of stretch-forming dies, it should be noted that the most advantageous design of the stretch-forming die is the design of a universal stretch-forming die of variable geometry. The use of this design will significantly reduce the labor costs for the manufacture of stretchforming dies. This design is required to be transported to the stretch-forming machine once. As a consequence, the time and material costs of transporting the stretch-forming die are reduced.

$* * *$

1. Rivin G.L., Karpukhin E. G., Koshkina A.O., Dmitrienko G.V. Method of Calculating the Research Mode of Antifriction properties of Coatings of Pulling Punches // Proceedings of the Samara Scientific Center of the Russian Academy of Sciences - 2018 - T.20 - №4 (3) - C. 414-416.

2. Zhua J.H., Wang H., Zhang W.H. and GU X.J. Aircraft Skin Stretch-Forming Die Light-Weight Design using Topology Optimization// Materials Science Forum Vol. 5 (2011).

3. Jian Xing, Yan-yan Cheng, and Zhuo Yi. The Effect of Swinging Ball Heads with Different Arrangements in Multi-Point Stretch-Forming Process//Materials. Vol. 10 (2019).

4. Stankevich A.V. Improving the technological process of stitching sheet metal parts of large thickness / A. V. Stankevich, I. V. Kremza, R. F. Krupsky, A. A. Krivenok // Future of Russian Engineering. - 2010. - P. 41-45.

5. Blau, P. J. Friction science and technology: from concepts to applications / Peter J. Blau. - 2nd ed. Vol.436 (2009)

\title{
Mitrofanova A.S. Air refueling without participation of pilots
}

Reshetnev Siberian State University of Science and Technology

(Russia, Krasnoyarsk)

doi: $10.18411 / \mathrm{j}-04-2019-239$

idsp: ljournal-04-2019-239

\section{Abstract}

In article problems of refueling of aircrafts, ways of their solution and also ways of refueling are considered.

Key word: refueling of aircrafts, automatic management system process of refueling of aircrafts.

\section{Аннотация}

В статье рассматриваются проблемы дозаправки воздушных судов, пути их решения, а также способы дозаправки.

Ключевые слова: дозаправка воздушных судов, автоматическая система управления процессом дозаправки воздушных судов.

The first aircraft flew for a short time, as they quickly ran out of fuel. So that the aircraft could fly for a long time without launching for refueling, in 1917 the Russian test pilot came up with a risky system of refueling the aircraft with fuel in the air. However, there is information that before there was a way to transfer cans of fuel from one aircraft to another with a long rope, but it was an inconvenient and dangerous way.

Then the Russian test pilot simplified a task, having created a special hose on which fuel from one aircraft on another by means of attracting force flew. That is, the aircraft with gasoline flew above other aircraft which was required to be filled, at the same time aircrafts flew slowly. Before it the hose needed to be caught and to manually insert its end into the fuel tank. Then the pumps simplifying refueling were not. Only by 1940 the hose was equipped with the pump, and refueling began to take place quicker. Thanks to refueling the aircraft can be airborne infinite time, of course, if the engine is operational and the pilot has a relief [1]. 
And so, today there are already 4 types of refueling of aircrafts: a hose loop, from a wing on a wing, a hose cone, a bar. Now the Air Force of Russia is armed only four types of the aircrafts capable to serve for refueling of other aircrafts in air: Il-78 air refueller, front SU24 bomber and deck SU-33 fighters and MiG-29K / MiG-29KUB.

The procedure of refueling of the aircraft very dangerous system having a huge impact on the pilot. Sometimes pilots call refueling - «air suicide». At air refueling pilots lose up to 4-5 kg of weight. During this procedure at absolutely healthy military pilot fixed pulse rate in 180-200 beats per minute (norm - 76-80), and in some cases it reached 220 blows. If the pilot assumes though the slightest error in refueling, it can lead to explosion of the aircraft, and is great the probability, as the refueling station [2].

Referring to the aforesaid, it is possible to suggest to solve this problem, having created automatic management system process of refueling of aircrafts. The automatic system means itself that pilots will only «watch» process of refueling of air tankers. For a role of implementation of this system the air tanker, such as, Il-78-2 (Il-78MD-90A) will approach.

The system will allow to carry out independently without participation of pilots refueling, on the basis of the obtained data from the sensors installed on aircraft. They will determine coordinates of a filling bar or a hose of the air refueller. Having obtained positive data on joining, the operator of gas station who is onboard «the flying tanker» turns on the fuel pump which pumps over fuel. All this operation is performed at constant radio exchange between the operator of gas station and the pilot of the aircraft recipient.

Work on interaction of sensors will remind the navigation system and stabilization installed on the spacecraft i.e. provides a certain provision of axes of the device of rather some set directions. The aircraft which obtained data from sensors will be built in the necessary situation for implementation of refueling of other aircraft.

This system considerably will facilitate both refueling, and the receiving load of pilots during this procedure. At the same time the operator will not be excluded from crew of the air refueller and will carry out supervision of work of automatic system and also to interfere with process of refueling during emergency situations.

Also passenger airliners will be able to use this system that will cause big economy of fuel, time, and bigger distance for flight of passengers.

Moreover, since 2012 action of a system of quoting of emissions in the environment extends also to activity of airlines. And it means, carriers acquire certificates on each ton of «exhausts», without saying already that the solution of one more problem from this will follow.

At the same time scientists note: over our territory there passes the majority of the air routes connecting Europe and Southeast Asia. The refuellings equipped with a system, the average trunk Tu-204 aircrafts and the perspective MS-21 aircraft would be on these airlines out of competition. The same can be told also about air transportation on lines of the USA Southeast Asia.

Specialists consider that the aircrafts of average range developed under technology of flights with air refueling in full sense will become «a disruptive product» on world aviation market. Moreover, refueling «will help» also for the supersonic passenger aircraft of the 2nd generation: take-off weight can be reduced from 400 to 140 tons, and it, according to scientists, solves key problems of the project [3].

$$
* * *
$$

1. https://vpolete.online/interesnoe/dozapravka-v-vozduhe.html

2. https://iz.ru/701878/sergei-valchenko-aleksei-ramm/dozapravku-v-vozdukhe-avtomatiziruiut

3. https://rg.ru/2011/04/06/dozapravka.html 